\title{
Use of Mixed Fuel Based on Brown Coal and its Thermal Processing Products in Energy Boilers
}

\author{
Andrei V. Zhuikov*a, \\ Anatoly I. Matiushenko ${ }^{a}$, Dmitry A. Loginov ${ }^{\text {b, }}$ \\ Anatoly M. Zhizhaev', Petr N. Kuznetsov', \\ Lyudmila S. Tarasovad and Grigory R. Mongush ${ }^{\mathrm{e}}$ \\ ${ }^{a}$ Siberian Federal University \\ Krasnoyarsk, Russian Federation \\ ${ }^{b}$ SIBNIIUGLEOBOGASCHENIE LLC \\ Krasnoyarsk, Russian Federation \\ cInstitute of Chemistry and Chemical Technology SB RAS \\ Krasnoyarsk, Russian Federation \\ ${ }^{d} F R C$, Krasnoyarsk Scientific Center SB of RAS \\ Krasnoyarsk, Russian Federation \\ ${ }^{e}$ Tuvinian Institute for Exploration \\ of Natural Resources of SB RAS \\ Kyzyl, Russian Federation
}

Received 15.12.2020, received in revised form 28.01.2021, accepted 21.02.2021

\begin{abstract}
The work investigated the thermal behavior of Borodino coal, brown coal coke and mixed fuel, consisting of $80 \%$ Borodino brown coal and $20 \%$ brown coal coke during the combustion process using thermogravimetric analysis. The chemical composition of the samples is presented. When analyzing the TG-DTG curves, combustion characteristics were determined, such as: ignition temperature $\left(\mathrm{T}_{\mathrm{i}}\right)$ and coke burnout temperature $\left(\mathrm{T}_{\mathrm{e}}\right)$, flammability index, integral combustion parameter. To determine $T_{i}$ and $T_{e}$, the technique of crossing the TG and DTG curves was applied and justified. An electron microscopic study of the cross-section of a lignite coke particle has been carried out. The results of the study showed that the addition of lignite coke to brown coal has a positive effect on its combustion characteristics.
\end{abstract}

Keywords: Coal, semi-coke, mixed fuel, ignition temperature, combustion, gasification, TG-DTG, low-carbon energy, resource conservation. 


\title{
Использование смесевого топлива на основе бурого угля и продуктов его термической переработки \\ в топках энергетических котлов
}

\author{
А.В. Жуйков*а, А.И. Матюшенко \\ Д.А. Логинов ${ }^{\sigma}$, А.М Жижаевв \\ П. Н. Кузнецов ${ }^{\text {в }, ~ Л . ~ С . ~ Т а р а с о в а ~}{ }^{\Gamma}$, Г.Р. Монгуш ${ }^{\text {д }}$ \\ ${ }^{a}$ Сибирский федеральный университет \\ Российская Федерация, Красноярск \\ ${ }^{\sigma} О О О$ «Сибнииуглеобогащение» \\ Российская Федераџия, Красноярск \\ ${ }^{6}$ Институт химии и химической технологии \\ ФИЦ КНЦ СО РАН \\ Российская Федераџия, Красноярск \\ ${ }^{2}$ ФИЦ Красноярский научный иентр СО РАН \\ Российская Федераџия, Красноярск \\ ${ }^{\text {д} Т у в и н с к и и ̆ ~ и н с т и т у т ~ к о м п л е к с н о г о ~ о с в о е н и я ~}$ \\ природных ресурсов \\ Российская Федерациия, Кызыл
}

\begin{abstract}
Аннотация. В работе исследовано термическое поведение бородинского угля, буроугольного кокса и смесевого топлива, состоящего из $80 \%$ бородинского бурого угля и $20 \%$ буроугольного кокса, во время процесса горения с помощью термогравиметрического анализа. Представлен химический состав образцов. При анализе кривых ТГ-ДТГ были определены следующие характеристики горения: температура воспламенения $\left(\mathrm{T}_{\mathrm{i}}\right)$ и температура выгорания коксового остатка $\left(\mathrm{T}_{\mathrm{e}}\right)$, индекс воспламеняемости, интегральный параметр горения. Для определения $\mathrm{T}_{\mathrm{i}}$ и $\mathrm{T}_{\mathrm{e}}$ была применена и обоснована методика пересечения кривых ТГ и ДТГ. Провели электронномикроскопическое исследование сечения частицы буроугольного кокса. Результаты исследования показали, что добавление буроугольного кокса к бурому углю оказывает положительное влияние на характеристики его горения.
\end{abstract}

Ключевые слова: уголь, буроугольный кокс, смесевое топливо, температура воспламенения, сжигание, газификация, ТГ-ДТГ, низкоуглеродная энергетика, ресурсосбережение.

Цитирование: Жуйков, А. В. Использование смесевого топлива на основе бурого угля и продуктов его термической переработки в топках энергетических котлов / А. В. Жуйков, А. И. Матюшенко, Д. А. Логинов, А.М Жижаев, П.Н. Кузнецов, Л. С. Тарасова, Г. Р. Монгуш // Журн. Сиб. федер. ун-та. Техника и технологии, 2021, 14(1). С. 106-117. DOI: 10.17516/1999494X-0291

\section{Введение}

Одной из приоритетных задач энергетической политики России является рациональное использование топливно-энергетических ресурсов и создания необходимых факторов для перехода страны к энергосберегающим экологически чистым направлениям развития теплоэнергетики. Переход к низкоуглеродной энергетике в рамках Парижского соглашения от 2015 г., согласно Рамочной конвенции ООН, набирает обороты по всему миру [1], включая и Россию. Безусловно, активнее всего на низкоуглеродную энергетику пытаются перейти страны, которые не имеют 
запасов ископаемого топлива в силу своего географического расположения либо эти запасы очень малы. Такие страны ищут разные способы вовлекать в свой топливный баланс различные виды биотоплива, при этом сталкиваясь со множеством трудностей, начиная от транспортировки, хранения, подготовки к сжиганию, снижения вредных выбросов при их сжигании (таких как бенз(а)пирен и др.) и заканчивая разработкой новых процессов сжигания, газификации, пиролиза, торрефикации. Сложнее всего тем странам, включая и Россию, где находятся большие запасы ископаемого топлива. Поэтому многие ученые не только в нашей стране, но и за рубежом пытаются ответить на вопрос, как можно применять ископаемое твердое топливо для получения дешевой электрической и тепловой энергии при минимальном содержании вредных веществ в продуктах его сгорания. Предложено большое количество способов, как это реализовать, но, к сожалению, все эти способы требуют огромных капиталовложений.

Топливно-энергетический комплекс Красноярского края, генерирующий тепловую и электрическую энергию на тепловых электрических станциях и промышленно-отопительных котельных, базируется на использовании бурых углей Канско-Ачинского бассейна (КАБ). Крупные электростанции (ТЭЦ, ГРЭС) составляют значительную часть генерации тепловой и электрической энергии, располагаясь в городах и возле градообразующих промышленных предприятий. В муниципальных районах края производство тепловой и электрической энергии осуществляется путем сжигания твердого, жидкого топлива и с применением электрокотельных. Доля котельных, сжигающих бурый уголь в крае, составляет 71,9 \%, на них вырабатывается 85,3 \% всей тепловой энергии. Повышению эффективности процессов сжигания бурого угля и водотопливных смесей, получаемых на его основе, и других технологий его использования посвящен целый ряд работ [2-8].

Основная цель проведенного исследования - определение характеристик горения смесевого топлива из бурого угля и продуктов его термической переработки.

\section{1. Материалы и методы}

\section{1. Материаль}

В качестве объектов исследования были взяты:

- бородинский бурый уголь (ББУ) с общей влагой 32,6 \%, для обеспечения возможности измельчения он предварительно подсушивался до аналитического состояния, при котором общая влага составляла 10 \% (ББУ(А), что соответствует характеристикам частиц угля, поступающих в топки пылеугольных котлов после пылеприготовительных агрегатов;

- буроугольный кокс (БК), полученный из балахтинского бурого угля марки 3Б;

- смесевое топливо, полученное путем смешения 80 \% ББУ и 20 \% БК.

Общий вид исходных образцов ББУ, ББУ(А) и БК показан на рис. 1. Основные характеристики топлив приведены в табл. 1.

БК был получен путем частичной газификации балахтинского угля в газификаторе шахтного типа с использованием эффекта «обратной тепловой волны» при температуре $800-900{ }^{\circ} \mathrm{C}[9$, 10]. Буроугольные коксы, полученные из бурых углей КАБ, применяют как высококалорийное бездымное топливо (бездымный уголь) и в качестве адсорбента. В данном исследовании буроугольный кокс рассматривался в качестве энергетического топлива. Большое содержание углерода в БК обеспечивает высокую теплоту его сгорания. В то же время БК обладает развитой открытой 


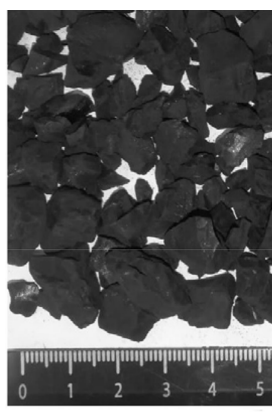

a

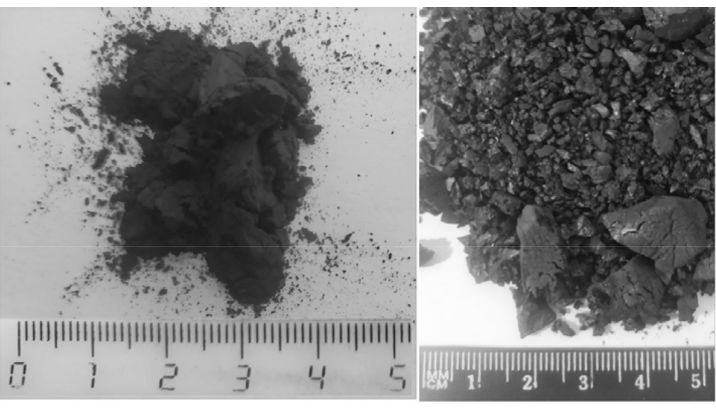

б

B

Рис. 1. Объекты исследования: а - бородинский уголь в рабочем состоянии; б - бородинский уголь в аналитическом состоянии; в - буроугольный кокс

Fig. 1. Research objects: a - Borodino coal in working condition; b - Borodino coal in analytical condition; c-semi-coke

Таблица 1. Химический состав и физико-технические характеристики топлив

Table 1. Chemical composition and physical and technical characteristics of fuels

\begin{tabular}{|c|c|c|c|c|c|}
\hline \multirow{2}{*}{\multicolumn{2}{|c|}{$\begin{array}{c}\text { Технический анализ } \\
\text { Аналитическое состояние }\end{array}$}} & ББУ(А) & ББУ & БК & \multirow[t]{2}{*}{$\begin{array}{c}80 \% \text { ББУ + } \\
+20 \% \text { БК }\end{array}$} \\
\hline & & \multicolumn{3}{|c|}{ Рабочее состояние } & \\
\hline Общая влага,\% & $W_{t}$ & 10,2 & 32,6 & 2,0 & 26,5 \\
\hline Зольность угля,\% & $\mathrm{A}$ & 6,5 & 4,9 & 9,6 & 5,8 \\
\hline Выход летучих,\% & $V$ & 38,3 & 28,8 & 4,2 & 23,9 \\
\hline $\begin{array}{l}\text { Низшая теплота сгорания, } \\
\text { ккал/кг }\end{array}$ & $Q_{i}$ & 5450 & 3900,0 & 6916 & 4503,2 \\
\hline Общая сера,\% & $S_{t}$ & 0,2 & 0,2 & 0,3 & 0,2 \\
\hline \multicolumn{2}{|c|}{ Элементный анализ } & $\begin{array}{c}\text { Аналитическое } \\
\text { состояние }\end{array}$ & \multicolumn{3}{|c|}{ Рабочее состояние } \\
\hline Углерод,\% & $C$ & 60,7 & 45,8 & 75,0 & 51,7 \\
\hline Водород,\% & $H$ & 4,3 & 3,2 & 1,4 & 2,9 \\
\hline Азот, $\%$ & $N$ & 0,9 & 0,6 & 0,9 & 0,7 \\
\hline Кислород,\% & $O_{d}$ & 17,2 & 12,9 & 4,1 & 11,1 \\
\hline
\end{tabular}

пористой структурой (рис. 2), благодаря чему является высокореакционным энергетическим топливом в отличие от классического кокса с закрытыми порами, получаемого из каменных углей.

Процентное соотношение компонентов смесевого топлива было выбрано с учетом проведенных технико-экономических расчетов, где учитывался возможный объем производства БК, затраты при его производстве и высокая зольность буроугольного кокса, которая может повлиять на шлакование поверхностей нагрева котла.

Низшая теплота сгорания всех трех образцов была рассчитана на основании результатов их аналитических испытаний по формуле Д. И. Менделеева:

$$
\begin{gathered}
Q_{\mathrm{H}}^{\mathrm{p}}=339 * C^{P}+1256 * H^{P}-109 *\left(\mathrm{O}^{P}-S_{L}^{P}\right)-25,14 *\left(9 * H^{P}+W^{P}\right), \\
-109-
\end{gathered}
$$


где $C_{P}, H_{p}, O_{P}, S_{L}^{P}, W_{p}$ - содержание в рабочей массе топлива углерода, водорода, кислорода, летучей серы и влаги, в \% (по массе).

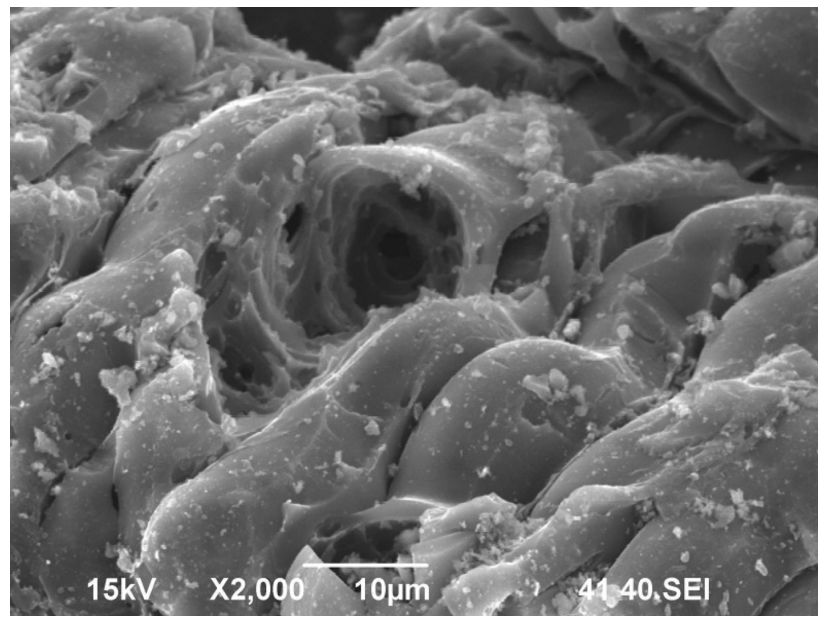

Рис. 2. СЭМ изображение сечения частицы буроугольного кокса

Fig. 2. SEM image of a cross-section of particle semi-coke

\section{2. Термогравиметрический анализ}

Комплексный термический анализ образцов проводился с применением синхронных термоанализаторов SDT Q600 (TA Instruments-Waters LLC, New Castle, DE, USA) и STA 449 Jupiter (фирмы NETZSCH). Анализатор STA 449 Jupiter оборудован квадрупольным массспектрометром QMS403 Aeolos, подключенным к STA с помощью линии подачи газов с постоянной температурой $230{ }^{\circ} \mathrm{C}$. Данные, полученные с масс-спектрометра, программно объединены с данными STA-системы. Анализатор STA 449 Jupiter позволял осуществлять одновременное измерение изменений массы (термогравиметрия), тепловых потоков (дифференциальная сканирующая калориметрия) и анализ газов, выделяющихся при нагревании образцов. Использовался платина/платинородиевый держатель (TG-DSC сенсор типа S) в сочетании с корундовыми тиглями.

Кривые ТГ и ДТГ снимали для навески топлива около 6 мг в потоке воздуха или аргона с расходом 50 мл/мин при скорости нагрева 10 и $20{ }^{\circ} \mathrm{C} /$ мин. Класс крупности образцов 100 300 мкм.

\section{3. Электронно-микроскопические исследования}

Для электронно-микроскопических (СЭМ) исследований буроугольного кокса брали 1-1,5 г образца, без дополнительного измельчения фиксировали в силиконовой форме эпоксидной смолой Epofix. После полимеризации полученную шашку сошлифовывали на 1-2 мм, шлифовали поверхность наждачной бумагой (P200-P2500) на шлифовальном станке TegraPol (Struers) и полировали корундовыми суспензиями 3М. Электронно-микроскопические исследования проводили на сканирующем электронном микроскопе TM4000 (Hitachi, Япония), обо- 
рудованном энергодисперсионным спектрометром и системой рентгеновского микроанализа Quantax150 (Bruker) в режиме низкого вакуума (без напыления платины).

\section{4. Характеристики горения образиов}

В данной работе были определены следующие характеристики горения [11]: температура воспламенения коксового остатка $\left(T_{\mathrm{i}}\right)$, температура выгорания коксового остатка $\left(T_{\mathrm{e}}\right)$, максимальная температура самой высокой скорости потери массы $\left(T_{\max }\right)$, максимальная скорость потери массы $\left(R_{\max }\right)$, индекс воспламеняемости (С) и интегральный параметр сгорания $\left(H_{f}\right) . T_{\mathrm{i}}$ и $T_{\mathrm{e}}$ определяли по пересечению касательных на кривых ТГ и ДТГ (рис. 3). $T_{\max }$ соответствует максимальной скорости потери массы у образцов $\left(R_{\max }\right)$. Для определения характеристик горения, изображенных на рис. 3, была использована программа Universal Analysis 2000.

Индекс воспламеняемости C, отражающий свойства воспламенения на ранней стадии горения, определялся по следующей формуле:

$$
\mathrm{C}=R_{\max } / T_{i}^{2}
$$

Он характеризует, насколько трудно или легко, как быстро или медленно топливо воспламеняется.

Интегральный параметр сгорания $H_{f}$ описывает весь процесс сжигания образцов, показывает скорость и интенсивность процесса горения, а также отражает стабильность поведения пламени после воспламенения образца. С уменьшением $H_{f}$ характеристики, влияющие на процесс горения, улучшаются. Интегральный параметр сгорания определялся по формуле

$$
H_{f}=T_{\max } \times \ln \left(\frac{\Delta T_{\frac{1}{2}}}{R_{\max }}\right) \times 10^{-3}
$$

где $\Delta \mathrm{T}_{1 / 2}$ - полуширина пика, которая представляет собою разницу температур между двумя температурами скорости потери массы, равной 0,5 от $\mathrm{R}_{\max }$.

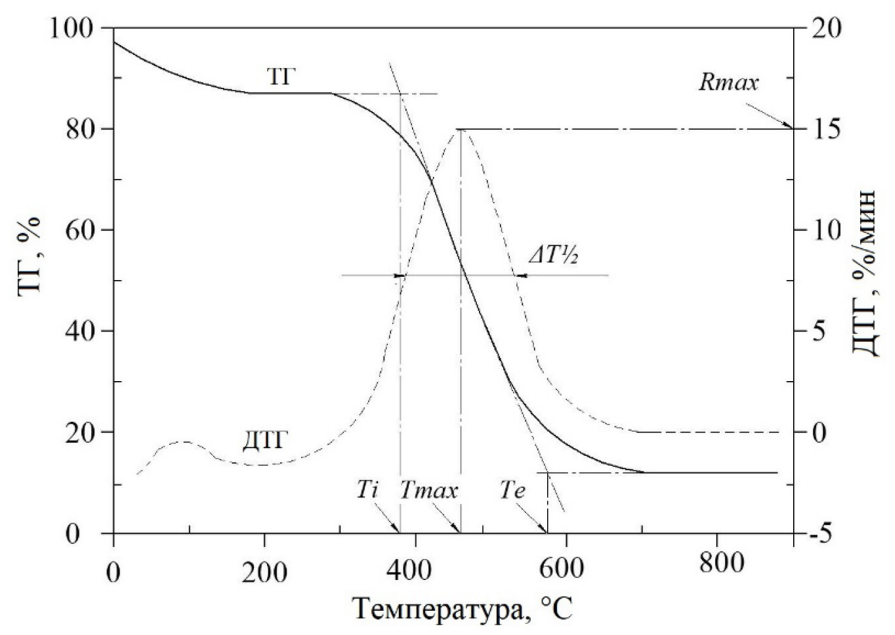

Рис. 3. Определение температур горения по кривым ТГ и ДТГ

Fig. 3. Determination of combustion temperatures from TG and DTG 


\section{2. Результаты и обсуждения}

\section{1. Обоснование выбора размера частии объектов исследования}

Предварительно было проверено влияние размера частиц бородинского угля на показатели горения. На рис. 4 приведены кривые ДТГ и ДСК при горении фракций угольных частиц разного размера при скорости нагрева $10{ }^{\circ} \mathrm{C} /$ мин. Видно, что выгорание угольных частиц происходит в температурной области $200-550{ }^{\circ} \mathrm{C}$ с выделением значительного количества тепла. Хотя температура начала горения практически мало зависит от размера частиц, скорость горения мелких частиц существенно выше, чем крупных. Как следствие, процесс выгорания мелких частиц заканчивается раньше при более низкой температуре (примерно, на $30-40{ }^{\circ} \mathrm{C}$ ).

Наблюдаемая различная динамика выгорания, вероятно, связана с влиянием внутренней диффузии при горении крупных частиц, что обусловлено, с одной стороны, высокой скоростью реакций горения, с другой - тонкопористым строением угля. Данные показывают, что на горение более крупных частиц (классы крупности менее 0,5 и 1,0 мм) оказывала влияние внутренняя диффузия, в случае мелких частиц (менее 0,2 мм) реакция протекала, возможно, в кинетической области без диффузионного торможения. С учетом полученных данных последующие термогравиметрические исследования осуществляли для фракции топлива с размером частиц 100-300 .

\section{2. Обоснование выбранной методики определения $T_{i}$}

Известно, что бурые угли сравнительно легко подвергаются термической деструкции. Этот процесс, сопровождаемый выделением летучих веществ, может вносить вклад в потерю массы при горении. Для оценки этого вклада предварительно были проведены опыты по термическому анализу бурого угля в токе воздуха и в тех же условиях в токе инертного газа аргона. Полученные ДТГ кривые (при скорости нагрева образцов $20^{\circ} \mathrm{C} / \mathrm{мин)}$ сопоставлены на рис. 5 . Из ДТГ кривых следует, что:

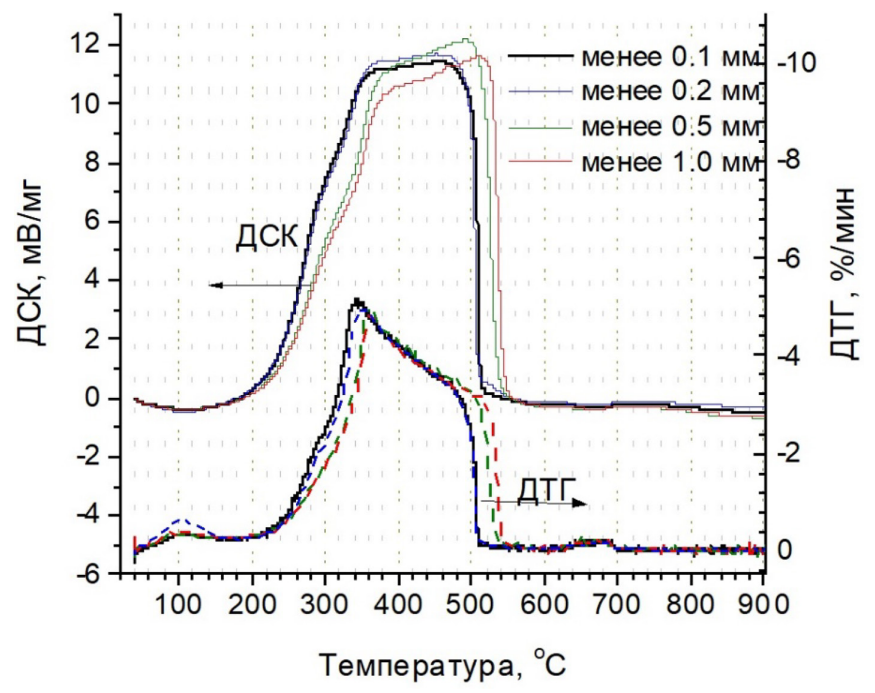

Рис. 4. Кривые ДТГ и ДСК при горении фракций угольных частиц бородинского угля разного размера

Fig. 4. DTG and DSC in the combustion of fractions of coal particles of Borodino coal of different sizes 


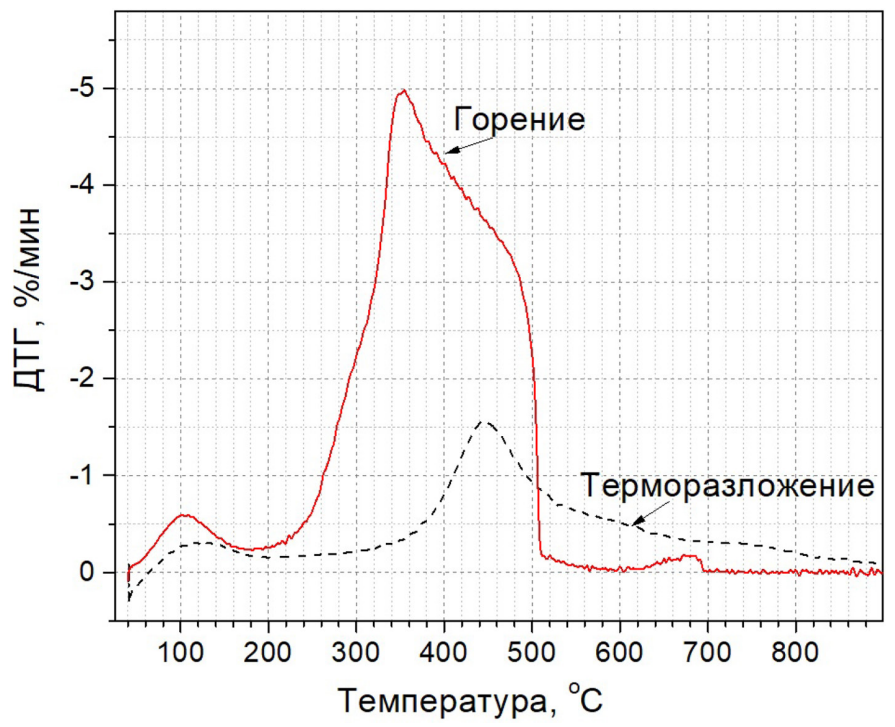

Рис. 5. Кривые ДТГ для бурого угля при пиролизе в среде аргона и при горении в токе воздуха

Fig. 5. DTG for brown coal during pyrolysis in argon and during combustion in air flow

- выделение летучих веществ в среде воздуха начинается при значительно более низкой температуре (около $220{ }^{\circ} \mathrm{C}$ ), чем процесс термической деструкции (примерно на $100{ }^{\circ} \mathrm{C}$ выше);

- выход и скорость выделения летучих веществ в воздушной среде многократно превышает соответствующие показатели в среде аргона.

Таким образом, видно, что продукты терморазложения органической массы угля не вносят существенного вклада в выделение летучих веществ при горении, данные ТГ и ДТГ в потоке воздуха могут быть использованы для изучения процесса горения.

\section{3. Обсуждение результатов основных исследований}

По данным табл. 1, БК имеет низшую теплоту сгорания выше, чем у ББУ, на $\approx 3000$ ккал/кг. Смешение бородинского угля с буроугольным коксом приводит к увеличению содержания в смесевом топливе углерода и снижению содержания кислорода в сравнении с ББУ, что наряду со снижением общей влаги топливной смеси вызывает рост низшей теплоты сгорания. Так, низшая теплота сгорания смесевого топлива, полученного путем смешения 80 \% масс. ББУ и 20 \% масс. БК, равна 4503 ккал/кг, что выше, чем у ББУ, на $\approx 600$ ккал/кг.

Характеристики горения объектов исследования определяли методом термического анализа по кривым ТГА и ДТГ в токе воздуха при скорости нагрева $20^{\circ} \mathrm{C} /$ мин. На рис. 6 приведены кривые ТГ и ДТГ горения бородинского угля. Процесс горения угля включает три основные стадии: прогрев и теплообмен угольной частицы с окружающей средой, воспламенение и горение летучих, воспламенение и горение обуглероженного остатка (кокса). Первый и второй этапы горения численно не определялись.

Третий этап начался с температуры воспламенения обуглероженного остатка $340{ }^{\circ} \mathrm{C}$ и продолжался горением углерода до $538{ }^{\circ} \mathrm{C}$. Температура максимума основного пика кривой ДТГ соответствует $404^{\circ} \mathrm{C}$. После основного максимума на кривой ДТГ наблюдается небольшой пик 


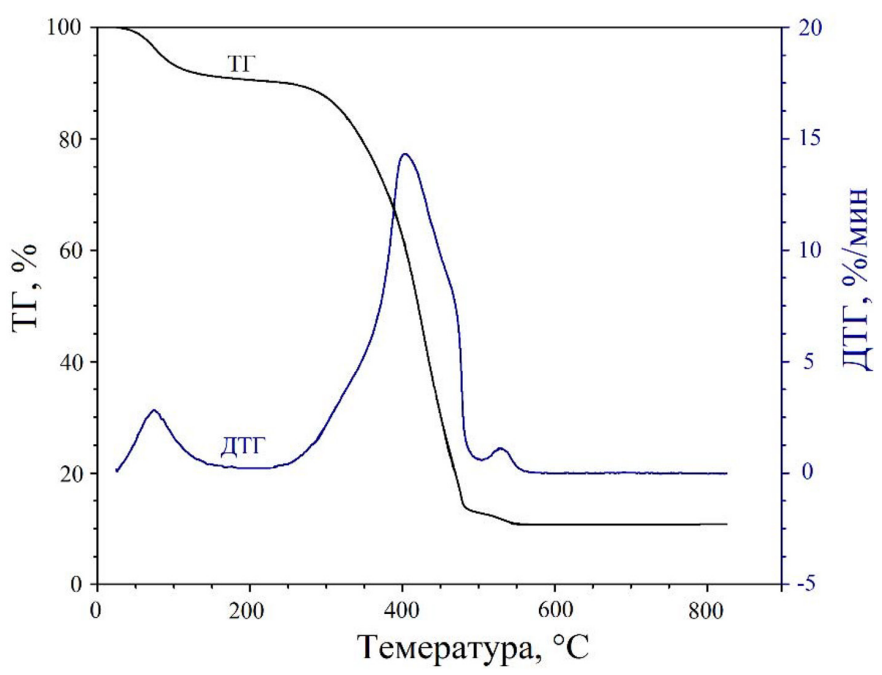

Рис. 6. Кривые ТГ и ДТГ горения бородинского угля в аналитическом состоянии

Fig. 6. TG and DTG combustion of Borodino coal

(при температуре $530^{\circ} \mathrm{C}$ ), который может быть связан с догоранием наиболее плотного углеродистого остатка либо с разложением минеральных веществ, содержащихся в угле, таких как доломит $\mathrm{CaCO}_{3} \cdot \mathrm{MgCO}_{3}$.

Воспламенение и горение БК начинаются при значительно более высокой температуре: воспламеняется при температуре $468{ }^{\circ} \mathrm{C}$, т. е. на $100{ }^{\circ} \mathrm{C}$ больше, чем уголь, а максимальная интенсивность горения происходит при $521{ }^{\circ} \mathrm{C}$. Это может быть связано с рядом факторов, в частности, с низким выходом летучих веществ, которые были удалены из исходного угля в процессе высокотемпературной частичной газификации, а также с особенностью состава буроугольного кокса (рис. 7).

Динамика горения смесевого топлива (рис. 8) похожа на горение угля. Температура максимальной скорости потери массы на кривой ДТГ составила $421{ }^{\circ} \mathrm{C}$. Воспламенение и сгорание обуглероженного остатка проходят в диапазоне температур от 354 до $543{ }^{\circ} \mathrm{C}$. На кривой ДТГ виден второй пик при температуре $501{ }^{\circ} \mathrm{C}$, в котором происходит горение обуглероженного остатка буроугольного кокса.

Основные характеристики горения сведены в табл. 2, из данных которой видно, что температура воспламенения буроугольного кокса намного выше температуры воспламенения угля. Температура воспламенения является одним из показателей реакционной способности топлива. Температура полного выгорания коксового остатка у БК $\left(552{ }^{\circ} \mathrm{C}\right)$ выше, чем у ББУ(А). Индекс воспламеняемости и интегральный параметр горения БК ниже, чем у ББУ(А), что также доказывает, что буроугольный кокс медленнее и труднее воспламеняется, интенсивность и скорость горения его меньше.

Как видно из данных табл. 2, добавление к углю буроугольного кокса улучшает характеристики горения получившегося топлива. Индекс воспламеняемости С смесевого топлива стал даже выше, чем у угля, что положительно сказывается на скорости воспламенения такого топлива. Интегральный параметр горения $H f$ снизился, что позволяет судить об увеличении 


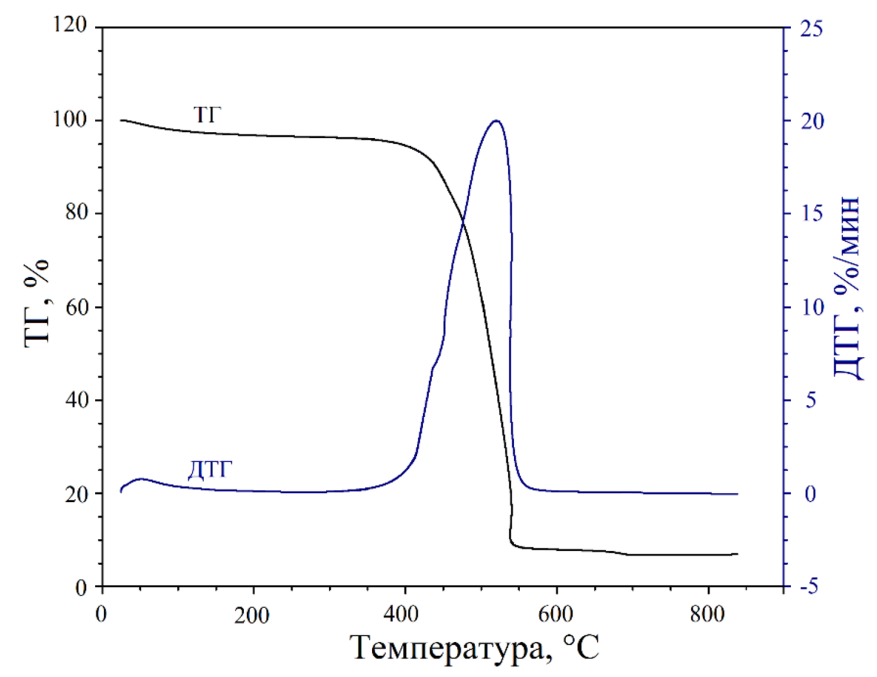

Рис. 7. Кривые ТГ и ДТГ горения буроугольного кокса

Fig. 7. TG and DTG combustion of semi-coke

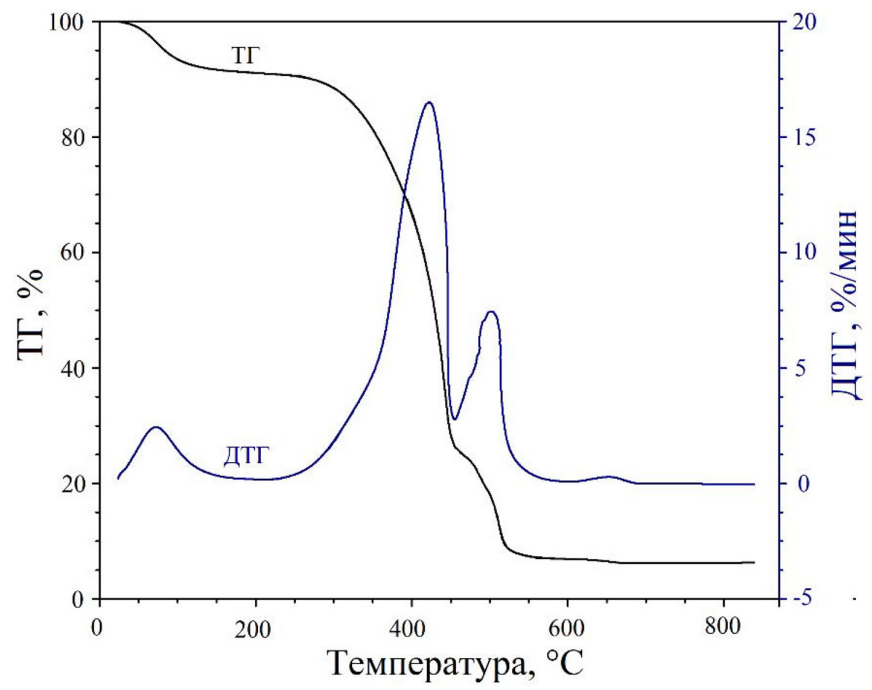

Рис. 8. Кривые ТГ и ДТГ горения смесевого топлива

Fig. 8. TG and DTG combustion of mixed fuel

интенсивности процесса горения, а также говорит о повышении стабильности поведения пламени после воспламенения топлива.

\section{Заключение}

Основным достоинством смесевого топлива является увеличение низшей теплоты сгорания по сравнению с бородинским углем. Применение такого топлива позволит сократить общий расход топлива на котле, что в свою очередь повлияет на снижение антропогенного воздействия на окружающую среду из-за снижения общего количества вредных выбросов. 
Таблица 2. Характеристики горения топлив

Table 2. Combustion characteristics of fuels

\begin{tabular}{|l|c|c|c|c|c|c|c|}
\hline & $T_{i},{ }^{\circ} \mathrm{C}$ & $T_{\max },{ }^{\circ} \mathrm{C}$ & $T_{e},{ }^{\circ} \mathrm{C}$ & $\begin{array}{c}R_{\max }, \% / \\
\text { мин }\end{array}$ & $\Delta T_{1 / 2},{ }^{\circ} \mathrm{C}$ & $C^{*} 10^{-5}$ & $H_{f}$ \\
\hline ББУ(А) & 343 & 404 & 538 & 14,15 & 112 & 12,02 & 0,83 \\
\hline БК & 468 & 521 & 552 & 19,80 & 85 & 9,04 & 0,76 \\
\hline $80 \%$ ББУ(A)+20\% БК & 354 & 421 & 543 & 16,40 & 71 & 13,10 & 0,62 \\
\hline
\end{tabular}

Происходит увеличение температуры воспламенения и температуры выгорания обуглероженного остатка у смесевого топлива по сравнению с бородинским углем, эти температуры зависят от времени протекания процесса нагревания объектов исследования. Из этого можно сделать вывод, что увеличение $T_{\mathrm{i}}$ и $T_{\mathrm{e}}$ говорит об увеличении временного интервала процесса горения. Для выгорания обуглероженного остатка смесевого топлива необходимо больше времени, чем для выгорания остатка бородинского угля.

Увеличение индекса воспламеняемости и снижение интегрального параметра горения позволяют судить об интенсификации воспламенения смесевого топлива и повышении стабильности процесса его выгорания, что также может положительно сказаться на повышении эффективности работы котельных агрегатов.

\section{Список литературы / References}

[1] Пыжев А. И., Ваганов Е. А. Роль российских лесов в реализации Парижского климатического соглашения: возможности или риски? Эко, 2019, (11), 27-44 [Pyzhev A. I., Vaganov E. A. Global climate change economics: the role of Russian forests, Eco, 2019, (11), 27-44 (In Russian)]

[2] Пат. 2722557 Российская Федерация МПК С10В49/10 Способ переработки угля/Степанов С.Г., Исламов С.Р., Логинов Д.А., Деменчук С. В., Концевой А. А.; патентообладатель Степанов С. Г.- № 2018113213; заявл. 11.04.2018; опубл. 01.06.2020 [Pat. 2722557 Russian Federation MPK C10B49/10 Coal processing method / Stepanov S. G., Islamov S. R., Loginov D. A., Demenchuk S. V., Kontsevoy A. A.; patent holder Stepanov S. G. - No. 2018113213; declared 04/11/2018; publ. 06/01/2020 (in Russian)]

[3] Логинов Д. А., Исламов С. Р., Степанов С. Г., Кочетков В. Н. Получение сорбента из низкозольного бурого угля. Химия твердого топлива, 2016, (2), 46-50 [Loginov D. A., Islamov S. R., Stepanov S. G., Kochetkov V.N. Obtaining sorbent from low-ash brown coal, Solid Fuel Chem., 2016, (2), 46-50 (In Russian)]

[4] Zhang K., Zhang K., Cao Y., Pan W. Co-combustion characteristics and blending optimization of tobacco stem and high-sulfur bituminous coal based on thermogravimetric and mass spectrometry analyses, Bioresour. Technol., 2013, 131, 325-332

[5] Zhao R., Qin J., Chen T., Wu J. TG-FTIR study on co-combustion of bituminous coal semicoke and lignite. JTAN. 2020

[6] Lu J., Chen W. Investigation on the ignition and burnout temperatures of bamboo and sugarcane bagasse by thermogravimetric analysis, Appl Energy, 2015, 160, 49-57

$$
-116-
$$


[7] Li X. G., Lv Y., Ma B. G., Jian S. W., Tan H. B. Thermogravimetric investigation on co-combustion characteristics of tobacco residue and high-ash anthracite coal, Bioresour. Technol., 2011, 102, 9783-9787

[8] Zheng Sh., Hu Y., Wang Zh., Cheng X. Experimental investigation on ignition and burnout characteristics of semi-coke and bituminous coal blends, J ENERGY INST., 2020, 93, 1373-1381

[9] Niu Sh., Han K., Lu Ch. Characteristic of coal combustion in oxygencarbon dioxide atmosphere and nitric oxide release during this process, ENERG CONVERS MANAGE, 2011, 52, 532-537

[10] Niu S. L., Lu C. M., Han K. H., Zhao J. L. Thermogravimetric analysis of combustion characteristics and kinetic parameters of pulverized coals in oxy-fuel atmosphere, Therm Anal Calorim, 2009, (98), 267-274

[11] Кузнецов П.Н., Колесникова С. М., Белаш М. Ю. Влияние минеральных компонентов на реакционную способность буроугольных карбонизатов при паровой газификации. Химия твердого топлива, 2011, (2), 60-64 [Kuznetsov P. N., Kolesnikov S. M., Belash M. Y. Influence of mineral components on reactivity of brown-coal carbonates during steam gasification, Solid Fuel Chem., 2011, (2), 60-64 (In Russian)] 